p-ISSN: $2338-4794$

e-ISSN: 2579-7476

Vol.8. No. 1 Januari-April 2020

\title{
PENGARUH CITRA MEREK DAN KUALITAS PRODUK TERHADAP KEPUTUSAN PEMBELIAN MOBIL HONDA JAZZ
}

\author{
Ajat Sudrajat ${ }^{1)}$ \\ 1) Dosen Fakultas Ekonomi, Unsika \\ Nuraini ${ }^{2)}$ \\ 2) Mahasiswa Fakultas Ekonomi Unsika \\ Muhammad Jazim Hamidi 3) \\ 3) Mahasiswa Fakultas Ekonomi Unsika \\ Email: ajat.sudrajat@fe.unsika.ac.id
}

\begin{abstract}
The purpose of this study to obtain the empirical evidence and to find clarity of phenomena and conclusions about the influence of these two variables above on Car Buying Honda Jazz Decision to consumers Honda Jazz in Karawang. Samples were collected by using Purposive Sampling with a sample of 100 respondents. Data analysis techniques used are Scale Range Analysis and Path Analysis with the help of Method of Successive Interval (MSI), Microsoft Excel 2010 and SPSS 21 computer programs. From the analysis of research data, obtained some conclusions are follows: Honda Jazz Car Image of 393.6 is on criteria Agreed. Quality of Honda Jazz Car Product of 382.2 is on criteria Agreed. Car Buying Honda Jazz decision of 398.53 is on criteria Agreed. There is a partial influence between Brand Image and Product Quality of 0.651. This shows a strong and undirectional relationship because it has a positive value. There is partial influence between Brand Image to Purchase Decision equal to $38.3 \%$ and there is partial influence between Product Quality to Purchase Decision equal to 47.3\%. There is simultaneous influence between Brand Image and Product Quality on Car Buying Decision of Honda Jazz to consumers in Karawang equal to 60.3\%, while the rest are other factors not examined equal to $39.7 \%$.
\end{abstract}

Keywords : Brand image, product quality, purchase decision

\section{PENDAHULUAN}

Di era yang semakin modern ini peningkatan perekonomian global semakin maju, banyak sekali perubahan - perubahan yang terjadi secara signifikan dari era sebelumnya. Hal ini memicu perdagangan bebas yang membuat dunia seolah tanpa adanya dinding pembatas. Banyak produsen barang dan jasa dari suatu negara yang bersaing dengan produsen negara lain untuk menarik minat konsumen dalam perdagangan internasional terutama pada bidang industri otomotif.
Perkembangan industri mobil di Indonesia telah mengalami kemajuan yang sangat cepat dan pesat. Selain itu perkembangan pembaruan produk mobil juga sangat diperhatikan sehingga bisa mencukupi selera konsumen yang bermacam - macam. Menyangkut kebutuhan masyarakat terhadap transportasi untuk kebutuhan berkendara keperluan pribadi yang semakin meningkat. Mengingat saat ini masyarakat Indonesia mempunyai peran penting dalam menumbuhkan perekonomian global. Saat ini Indonesia menjadi salah satu pasar potensial di bidang otomotif di kawasan ASEAN dan sekaligus 
berpeluang menjadi pemeran utama. Masyarakat Indonesia sekarang ini sudah menjadi konsumtif akan kebutuhan alat transportasi. Secara keseluruhan, total produksi kendaraan bermotor (mobil) sekarang sudah mencapai 2 juta unit per tahun, dan otomotif pun telah dimasukan dalam salah satu prioritas dalam Masyarakat Ekonomi Asean (MEA).

Salah satu survei merek di Indonesia yang dijadikan sebagai indikator kinerja sebuah merek adalah Top Brand Award. Survei ini dipelopori oleh majalah marketing yang bekerja sama dengan lembaga survei Frontier Consulting Group. Konsep tentang Top Brand mengenai merek suatu produk didasarkan pada tiga parameter yaitu : merek yang paling diingat (top of mind), merek yang terakhir kali dibeli atau dikonsumsi (last used), serta merek yang akan dipilih kembali dimasa mendatang (future intention). Ketiga parameter tersebut diformulasikan dengan cara menghitung rata - rata bobot masing - masing parameter untuk membentuk Top Brand Index (TBI). Kriteria yang harus dipenuhi agar semua merek berhak menyandang predikat Top Brand adalah memperoleh Top Brand Index minimum sebesar $10 \%$ dan berada dalam top three di dalam kategori produknya.

Berdasarkan data yang diperoleh peneliti dari Top Brand Index terlihat bahwa Honda Jazz selalu menempati posisi pertama sejak tahun 2016 sampai tahun 2018 dalam kategori mobil segmen City Car. Dapat dilihat pula Honda Jazz mengalami penjualan yang tidak stabil. Pada tahun 2017, Honda Jazz mengalami peningkatan penjualan sebesar 1,5\% dari tahun 2016, 22,5\% menjadi $24,0 \%$ dan kemudian pada tahun 2018, mengalami penurunan penjualan sebesar $3,6 \%$ dari tahun 2017, 24,0\% menjadi 20,4\%. Predikat Top Brand menjadi apresiasi atas upaya Honda sebagai pesaing ketat Toyota dalam membangun Top of Mind Share, Top of Market Share, dan Top of Commitmennt Share.

Adapun definisi Keputusan pembelian menurut Kotler dan Keler (2009) bahwa: Keputusan pembelian adalah keputusan konsumen terhadap merek terpilih diantara kumpulan pilihan merek - merek yang ada.

Salah satu nilai utama yang diharapkan oleh konsumen dari produsen sebelum memutuskan pembelian ialah Citra Merek yang baik. Citra merek sangat erat kaitannya dengan Keputusan Pembelian. Dimana Citra Merek menjadi salah satu aspek yang dipertimbangkan konsumen dalam melakukan Keputusan pembelian. Adapun pengertian Citra merek Menurut Supranto (2011) mengatakan: Citra merek (brand image) ialah apa yang konsumen pikir atau rasakan ketika mereka mendengar atau melihat nama suatu merek atau pada intinya apa yang konsumen telah pelajari tentang merek.

Hubungan antara keputusan pembelian dan citra merek menurut Kotler (2008) "keputusan pembelian seseorang dipengaruhi oleh adanya faktor citra merek sebagai keyakinan ide dan kesan yang dimiliki oleh seseorang terhadap suatu merek".

Dalam teori hubungan diatas citra merek adalah bagian dari keyakinan ide dan kesan terhadap suatu merek, karena itu sikap dan tindakan konsumen terhadap suatu merek sangat ditentukan oleh citra merek tersebut.

Selain citra merek dan keputusan pembelian mobil Honda Jazz juga dipengaruhi oleh kualitas produk. Menurut Feingenbaum dalam 
Marwanto (2015) menyatakan bahwa: "kualitas produk merupakan seluruh gabungan karakteristik produk dari pemasaran, rekayasa (perencanaan), pembuatan (produk) dan pemeliharaan yang membuat produk yang digunakan memenuhi harapan - harapan pelanggan".

Adapun pengertian kualitas produk menurut Kotler dan Keller (2016) mengatakan bahwa kualitas produk adalah kemampuan suatu barang untuk memberikan hasil atau kinerja yang sesuai bahkan melebihi dari apa yang diinginkan pelanggan.

Dari uraian diatas, tujuan penelitian ini adalah untuk melakukan sesuatu penelitian di Karawang guna mengetahui, menganalisis dan menjelaskan faktor apa saja yang mempengaruhi Citra Merek dan Kualitas Produk terhadap Keputusan Pembelian. Diharapkan pula penelitian ini dapat digunakan sebagai pengembangan ilmu manajemen terutama di bidang pemasaran dan dapat dijadikan acuan referensi bagi peneliti selanjutnya.

\section{LANDASAN TEORI}

\section{Citra Merek}

Pengertian Citra Merek menurut Kotler dan Keller (2012) adalah persepsi masyarakat terhadap perusahaan atau produknya.

Menurut Tjiptono (2011) Citra Merek merupakan deskripsi tentang asosiasi dan keyakinan konsumen tentang merek tertentu. Sedangkan asosiasi merupakan atribut yang ada didalam merek itu dan memiliki suatu tingkat kekuatan.

Kotler dan Amstrong (2012) merek adalah suatu nama, kata, tanda, simbol, atau desain atau kombinasi dari semuanya yang mengidentifikasikan pembuat atau penjual produk dan jasa tertentu.
Menurut Simamora (2011) manfaat merek yaitu: a). Bagi konsumen, brand dapat menceritakan sesuatu kepada pembeli tentang mutu dan membantu menarik perhatian pembeli terhadap produk - produk baru yang mungkin bermanfaat bagi mereka. b). Bagi produsen, brand dapat memudahkan penjual mengolah pesanan dan menelusuri masalah masalah yang timbul, memberikan perlindungan hukum atas ciri khas produk dan memungkinkan untuk menarik sekelompok pembeli yang setia dan menguntungkan. c). Bagi publik, brand memungkinkan mutu produk lebih terjamin dan lebih konsisten, meningkatkan efisiensi pembeli karena menyediakan informasi tentang produk dan dimana membelinya serta meningkatnya inovasi baru karena produsen terdorong untuk menciptakan keunikan baru guna mencegah peniruan dari pesaing.

Dari pengertian diatas dapat dikatakan bahwa Brand Image merupakan persepsi masyarakat tentang merek tertentu yang dapat digambarkan dengan kata, tanda, simbol atau desain atau kombinasi dari semuanya.

Dalam Keller (2013) menjelaskan indikator - indikator citra merek sebagai berikut: 1). Identitas Merek: identitas fisik yang berkaitan dengan merek atau produk tersebut sehingga pelanggan mudah mengenali dan membedakannya dengan merek atau produk lain, seperti logo, warna, kemasan, lokasi, identitas perusahaan yang memayungi, slogan, dan lain lain. 2). Personalitas Merek: karakter khas sebuah merek yang membentuk kepribadian tertentu sebagaimana layaknya manusia, sehingga khalayak pelanggan dengan mudah membedakannya dengan merek lain dalam kategori yang sama, misalnya 
karakter tegas, kaku, berwibawa, ningrat, atau murah senyum, hangat, penyayang, berjiwa sosial, atau dinamis, kreatif, independen, dan sebagainya. 3). Asosiasi Merek: hal hal spesifik yang pantas atau selalu dikaitkan dengan suatu merek, bisa muncul dari penawaran unik suatu produk, aktivitas yang berulang dan konsisten misalnya dalam hal sponsorship atau kegiatan sosial resposibility, isu - isu yang sangat kuat berkaitan dengan merek tersebut, ataupun person, simbol - simbol dan makna tertentu yang sangat kuat melekat pada suatu merek. 4). sikap dan perilaku merek: sikap atau perilaku komunikasi dan interaksi merek dengan pelanggan dalam menawarkan benefit - benefit dan nilai yang dimilikinya. Attitude and behavior mencakup sikap dan perilaku pelanggan, aktivitas dan atribut yang melekat pada merek saat berhubungan dengan khalayak pelanggan, termasuk perilaku karyawan dan pemilik merek. 5). Manfaat dan Keunggulan Merek: nilai - nilai dan keunggulan khas yang ditawarkan oleh suatu merek kepada pelanggan yang membuat pelanggan dapat merasakan manfaat karena kebutuhan, keinginan, mimpi, dan obsesinya terwujudkan oleh apa yang ditawarkan tersebut.

\section{Kualitas Produk}

Pengertian Kualitas Produk

Menurut Amstrong (2012) kualitas produk adalah segala sesuatu yang dapat ditawarkan ke pasar untuk mendapatkan perhatian, dibeli, digunakan, atau dikonsumsi yang dapat memuaskan keinginan atau kebutuhan.

Menurut Kotler dan Keller (2013) mengungkapkan bahwa kualitas produk adalah kualitas produk atau jasa yang bergantung pada kemampuan untuk memuaskan kebutuhan pelanggan yang dinyatakan atau diimplikasikan.
Dari pengertian para ahli diatas dapat diartikan bahwa kualitas produk merupakan segala sesuatu yang dapat ditawarkan ke konsumen untuk memenuhi kebutuhan atau keinginan konsumen.

Berikut adalah indikator indikator kualitas produk menurut Adam \& Ebert (2012) : 1). Manfaat: kualitas produk ditentukan oleh manfaat yang diberikan kepada pemakaianya. Contoh dari manfaat sebuah produk: Manfaat penggunaan, Manfaat psikologis, Manfaat dalam mengatasi masalah. 2). Visualisasi Produk: selain manfaat bentuk atau tampilan sebuah produk menentukan kualitas produk. Berikut ini aspek visualisasi produk: Atribut dan keistimewaan produk, Kualitas produk, Corak produk, Kemasan dan label produk. 3). Nilai Produk: merupakan sebuah penentu kualitas produk. Berikut ini aspek nilai produk: Garansi, Pengiriman, Ketersediaan di pasar, Layanan purna jual.

\section{Keputusan Pembelian}

Pengertian keputusan pembelian menurut Kotler (2012) adalah tahap dalam proses pengambilan keputusan dimana konsumen benar - benar membeli. Menurut Kotler dan Keller (2012) menyatakan terdapat lima tahap keputusan pembelian dilakukan oleh konsumen Pelanggan yaitu: 1). Pemilihan Produk, konsumen mengambil keputusan untuk membeli sebuah produk atau menggunakan uangnya untuk tujuan yang lain. Dalam hal ini perusahaan harus memusatkan perhatiannya kepada orang - orang yang berminat membeli produknya. 2). Pemilihan Merek, konsumen harus mengambil keputusan tentang merek mana yang akan dibeli. Setiap merek mempunyai perbedaan tersendiri. Dalam hal ini perusahaan harus mengetahui bagaimana konsumen 
memilih sebuah merek. 3). Pemilihan Saluran Pembelian, konsumen harus mengambil keputusan tentang penyalur mana yang akan dikunjungi. Setiap konsumen berbeda - beda dalam hal menentukan penyalur biasanya dikarenakan faktor lokasi yang dekat, harga yang murah, persediaan barang yang lengkap, kenyamanan belanja, keluasan tempat dan sebagainya. 4). Jumlah Pembelian, konsumen dapat mengambil keputusan seberapa banyak produk yang akan dibelinya. Dalam hal ini perusahaan harus mempersiapkan banyaknya produk sesuai dengan kebutuhan konsumen. 5). Waktu Pembelian, keputusan konsumen dalam waktu pembelian bisa berbeda - beda, misalnya: ada yang membeli setiap hari, seminggu sekali, dua minggu sekali, bahkan satu bulan sekali tergantung kebutuhannya.

Menurut Mangkunegara (1998) dalam penelitian (Wenas, Tumbel dan Parengkuan 2014) perilaku konsumen adalah kerangka kinerja atau sesuatu yang mewakili apa yang diyakini konsumen dalam mengambil keputusan membeli.

Menurut Schiffman et al (Schiffman, 2010) dalam penelitian (Djatmiko and Pradana 2016) disebutkan bahwa keputusan pembelian adalah tindakan yang dilakukan oleh konsumen untuk membuat keputusan dalam bentuk pemilihan produk, pemilihan merek, kondisi (diskon), dan jumlah pembelian.

Dari beberapa definisi diatas dapat diartikan bahwa keputusan pembelian adalah tahap dimana konsumen benar - benar membeli produk dengan mempertimbangkan produk, merek, kondisi, dan juga jumlah barang yang akan dibeli.

Berikut adalah indikator indikator yang sesuai dengan observasi pada peneliian ini menurut Kotler \& Armstrong (2016): 1). Pilihan Produk: konsumen dapat mengambil keputusan untuk membeli sebuah produk atau menggunakan uangnya untuk tujuan yang lain. Dalam hal ini perusahaan harus memusatkan perhatiannya kepada orang-orang yang berminat membeli sebuah produk serta alternatif yang mereka pertimbangkan. 2). Pilihan merek: konsumen harus mengambil keputusan tentang merek nama yang akan dibeli setiap merek memiliki perbedaan sendiri. Dalam hal ini perusahaan harus mengetahui bagaimana konsumen memilih sebuah merek. 3). Metode pembayaran: konsumen dapat mengambil keputusan tentang metode pembayaran yang akan dilakukan dalam pengambilan keputusan menggunakan produk atau jasa. Saat ini keputusan pembelian dipengaruhi oleh tidak hanya dari aspek lingkungan dan keluarga, keputusan pembelian juga dipengaruhi oleh teknologi yang digunakan dalam transaksi pembelian.

\section{Hipotesis}

Hipotesis dalam penelitian ini sebagai berikut: 1). Citra merek berpengaruh positif terhadap keputusan pembelian. 2). Kualitas produk berpengaruh positif terhadap keputusn pembelian. 3). Citra merek dan kualitas produk berpengaruh positif terhadap keputusan pembelian secara simultan.

\section{METODE PENELITIAN}

\section{Variabel Penelitian}

Variabel penelitian adalah segala sesuatu yang berbentuk apa saja yang ditetapkan oleh peneliti untuk dipelajari sehingga diperoleh informasi tentang hal tersebut, kemudian ditarik kesimpulannya (Sugiyono, 2013). Dalam penelitian ini terdapat variabel independen (bebas) dan variabel dependen (terikat). Variabel independen adalah variabel yang 
mempengaruhi atau yang menjadi sebab perubahannya atau timbulnya variabel dependen (Sugiyono, 2013). Variabel independen dalam penelitian ini yaitu citra merek $\left(X_{1}\right)$ dan kualitas produk $\left(\mathrm{X}_{2}\right)$. Variabel dependen adalah variabel yang dipengaruhi atau yang menjadi akibat, karena adanya variabel bebas. Variabel dependen dalam penelitian ini yaitu keputusan pembelian (Y).

\section{Metode Pengumpulan Data}

Teknik pengumpulan data merupakan cara mengumpulkan data yang dibutuhkan untuk menjawab rumusan masalah penelitian. Umumnya cara mengumpulkan data dapat menggunakan teknik wawancara, angket, pengamatan, studi dokumentasi dan focus group discussion. Juliansyah Noor (2011). Populasi adalah keseluruhan objek penelitian. Jadi, populasi bukan hanya orang, tetapi juga objek dan benda - benda alam yang lain. Populasi juga bukan sekedar jumlah yang ada pada objek atau subjek yang dipelajari, tetapi meliputi seluruh karakteristik atau sifat yang dimiliki oleh objek yang diteliti itu (Sugiyono, 2013). Populasi adalah jumlah keseluruhan dari obyek yang akan diteliti. Populasi pada penelitian ini adalah konsumen mobil Honda Jazz di Karawang.

Sugiyono (2013) menjelaskan sampel adalah bagian dari jumlah dan karakteristik yang dimiliki oleh populasi tersebut. Bila populasi besar, dan peneliti tidak mungkin mempelajari semua yang ada pada populasi, misalnya karena keterbatasan dana, tenaga, dan waktu, maka peneliti dapat menggunakan sampel yang diambil dari populasi itu.

Berdasarkan hasil pertimbangan, maka jumlah sampel yang digunakan adalah 96 responden. Agar penelitian ini menjadi lebih fit maka sampel diambil menjadi 100 responden. Jadi, jumlah sampel yang akan dipakai dalam penelitian ini adalah berjumlah 100 responden. Teknik pengambilan sampel yang digunakan adalah teknik non probability sampling dengan pendekatan puposive sampling yaitu pengambilan sampel dilakukan dengan pertimbangan-pertimbangan tertentu, dengan memperhatikan responden yang dikehendaki.

\section{Metode Analisis Data}

Teknik analisis data adalah suatu cara pengukuran, pengolahan dan analisis data dalam rangka pengujian hipotesis. Pengolahan data bertujuan untuk memberikan keterangan yang berguna, serta untuk menguji hipotesis yang telah dirumuskan dalam penelitian. Teknik analisis data dalam penelitian ini diarahkan pada pengujian hipotesis serta menjawab masalah yang diajukan.

Alat penelitian yang digunakan dalam penelitian ini adalah angket kuisioner. Angket disusun berdasarkan variabel yang terdapat dalam penelitian, yaitu memberikan keterangan dan data mengenai pengaruh citra merek dan kualitas produk terhadap keputusan pembelian. 
Tabel-1 Kriteria Penafsiran Hasil Perhitungan Responden

\begin{tabular}{ccc}
\hline No & Kriteria & Keterangan \\
\hline 1 & $0 \%$ & Tidak seorang pun \\
2 & $1 \%-25 \%$ & Sebagian kecil \\
3 & $26 \%-49 \%$ & Hampir setengahnya \\
4 & $50 \%$ & Setengahnya \\
5 & $51-75 \%$ & Sebagian besar \\
6 & $76 \%-99 \%$ & Hampir Seluruhnya \\
7 & $100 \%$ & Seluruhnya \\
\hline
\end{tabular}

Variabel bebas dari penelitian ini adalah citra merek dan kualitas produk Variabel terikat dari peneitian ini adalah keputusan pembelian (Y).

Kegiatan analisis data dalam penelitian ini yaitu: 1). Menyusun data, kegiatan ini dilakukan untuk mengecek kelengkapan identitas responden, kelengkapan data dan pengisian data yang disesuaikan dengan tujuan penelitian. 2). Tabulasi data, tabulasi data dalam penelitian ini dilakukan melalui bertahap yaitu: a). Memberi skor pada setiap item. b). Menjumlahkan skor pada setiap item. c). Menyusun ranking skor pada setiap variabel penelitian.

\section{Transformasi Data / MSI (Methode of Successive Interval)}

Transformasi data, berasal dari transform, merubah bentuk data. Pada pendekatan analisis jalur sering digunakan tipe data skala likert. Tipe data tersebut merefleksikan perubahan yang sebelumnya berasal dari suatu konsep yang sudah diubah bentuknya sehingga dapat diukur. Analisis jalur membutuhkan perhitungan matematis didalamnya. Oleh karena itu skala pengukuran data yang dibutuhkan minimal berskala interval. Jika data yang akan dianalisis berskala likert, maka perlu ditransformasikan terlebih dahulu menjadi skala interval agar dapat digunakan untuk analisis lebih lanjut. Metode transformasi data tersebut umumnya menggunakan uji MSI (Method of Successive Interval).

\section{HASIL DAN PEMBAHASAN}

\section{Hasil Penelitian}

Validitas menunjukan sejauh mana skor/nilai ukuran yang diperoleh benar - benar menyatakan hasil pengukuran/pengamatan. Validitas pada umumnya dipersalahkan berkaitan dengan hasil pengukuran psikologis atau non fisik. Berkaitan dengan karakteristik psikologis, hasil pengukuran yang diperoleh sebenarnya diharapkan dengan menggambarkan atau memberikan skor/nilai suatu karakteristik lain yang menjadi perhatian utama. Macam validitas umumnya digolongkan dalam tiga kategori besar, yaitu validitas isi (content validity), validitas konstruk dan validitas eksternal. Untuk mengunjungi apakah itu pertanyaan pertanyaan itu telah mengukur aspek yang sama digunakan validitas konstruk. Jika suatu Instrumen dapat dipercaya maka data yang dihasilkan oleh Instrumen tersebut dapat dipercaya juga. Dari hasil pengujian menunjukan bahwa sebanyak 45 butir pernyataan yang diajukan dinyatakan valid dan reliabel dan dapat dikatakan pula ketiga variabel pada penelitian ini dapat dipercaya. 
Tabel-2 Hasil Pengujian Validitas Citra Merek

\begin{tabular}{|c|c|c|c|c|}
\hline No. & Pertanyaan & $r$ tabel & r hitung & Kete \\
\hline \multicolumn{5}{|c|}{ Atribut } \\
\hline 1 & $\begin{array}{l}\text { Logo mobil Honda Jazz mudah } \\
\text { dikenal }\end{array}$ & 0,1654 & 0,690 & \multirow{3}{*}{$\begin{array}{l}r \text { hitung }>r \text { tabel maka } \\
\text { pernyataan valid } \\
r \text { hitung }>r \text { tabel maka } \\
\text { pernyataan valid } \\
r \text { hitung }>r \text { tabel maka } \\
\text { pernyataan valid }\end{array}$} \\
\hline 2 & $\begin{array}{l}\text { Mobil Honda Jazz mudah dikenal } \\
\text { di Masyarakat }\end{array}$ & 0,1654 & 0,722 & \\
\hline 3 & $\begin{array}{lrr}\text { Harga mobil } & \text { Honda Jazz yang } \\
\text { ditawarkan } & \text { sesuai } & \text { dengan } \\
\text { pendapatan konsumen }\end{array}$ & 0,1654 & 0,777 & \\
\hline \multicolumn{5}{|c|}{ Benefit (Manfaat) } \\
\hline 4 & $\begin{array}{l}\text { Mobil Honda Jazz mudah untuk } \\
\text { digunakan }\end{array}$ & 0.1654 & 0,756 & \multirow{3}{*}{$\begin{array}{l}r \text { hitung }>r \text { tabel maka } \\
\text { pernyataan valid } \\
r \text { hitung }>r \text { tabel maka } \\
\text { pernyataan valid } \\
r \text { hitung }>r \text { tabel maka } \\
\text { pernyataan valid }\end{array}$} \\
\hline 5 & $\begin{array}{l}\text { Mobil Honda Jazz sangat efektif } \\
\text { untuk keperluan keluarga }\end{array}$ & 0.1654 & 0,679 & \\
\hline 6 & $\begin{array}{l}\text { Mobil Honda Jazz irit bahan bakar } \\
\text { sesuai dengan harapan konsumen }\end{array}$ & 0.1654 & 0,760 & \\
\hline \multicolumn{5}{|c|}{ Value (Nilai) } \\
\hline 7 & $\begin{array}{l}\text { Mobil Honda Jazz memiliki mesin } \\
\text { yang berkualitas baik }\end{array}$ & 0.1654 & 0,586 & \multirow{2}{*}{$\begin{array}{l}\mathrm{r} \text { hitung }>\mathrm{r} \text { tabel maka } \\
\text { pernyataan valid } \\
\mathrm{r} \text { hitung }>\mathrm{r} \text { tabel maka } \\
\text { pernyataan valid }\end{array}$} \\
\hline 8 & 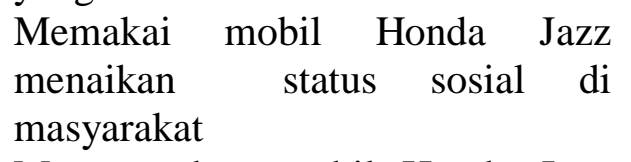 & 0.1654 & 0,665 & \\
\hline 9 & $\begin{array}{l}\text { Menggunakan mobil Honda Jazz } \\
\text { dapat meningkatkan gaya hidup }\end{array}$ & 0.1654 & 0,677 & $\begin{array}{l}\mathrm{r} \text { hitung }>\mathrm{r} \text { tabel maka } \\
\text { pernyataan valid }\end{array}$ \\
\hline \multicolumn{5}{|c|}{ Culture (Budaya) } \\
\hline 10 & $\begin{array}{l}\text { Mobil Honda Jazz } \quad \text { ramah } \\
\text { lingkungan }\end{array}$ & 0.1654 & 0,659 & \multirow{2}{*}{$\begin{array}{l}\mathrm{r} \text { hitung }>\mathrm{r} \text { tabel maka } \\
\text { pernyataan valid } \\
\mathrm{r} \text { hitung }>\mathrm{r} \text { tabel maka } \\
\text { pernyataan valid }\end{array}$} \\
\hline 11 & $\begin{array}{l}\text { Mobil Honda Jazz merupakan } \\
\text { mobil yang sangat elegan }\end{array}$ & 0.1654 & 0,780 & \\
\hline \multicolumn{5}{|c|}{ Personality (Kepribadian) } \\
\hline 12 & $\begin{array}{l}\text { Mobil Honda Jazz memiliki body } \\
\text { mobil yang mudah untuk diingat }\end{array}$ & 0.1654 & 0,811 & \multirow{2}{*}{$\begin{array}{l}\mathrm{r} \text { hitung }>\mathrm{r} \text { tabel maka } \\
\text { pernyataan valid } \\
\mathrm{r} \text { hitung }>\mathrm{r} \text { tabel maka } \\
\text { pernyataan valid }\end{array}$} \\
\hline 13 & $\begin{array}{l}\text { Mobil Honda Jazz memiliki desain } \\
\text { yang sangat unik }\end{array}$ & 0.1654 & 0,643 & \\
\hline \multicolumn{5}{|c|}{ User (Pemakai) } \\
\hline 14 & $\begin{array}{l}\text { Memiliki mobil } \\
\text { mencerminkan } \\
\text { menengah keatas }\end{array}$ & 0.1654 & 0,793 & $\begin{array}{l}\mathrm{r} \text { hitung }>\mathrm{r} \text { tabel maka } \\
\text { pernyataan valid }\end{array}$ \\
\hline 15 & $\begin{array}{l}\text { Pemilihan mobil } \begin{array}{l}\text { Honda Jazz } \\
\text { membutuhkan }\end{array} \\
\text { kembelinya }\end{array}$ & 0.1654 & 0,705 & $\begin{array}{l}\mathrm{r} \text { hitung }>\mathrm{r} \text { tabel maka } \\
\text { pernyataan valid }\end{array}$ \\
\hline
\end{tabular}

Sumber : Hasil Pengolahan Data 2019, software Pengolahan Data 2019

Instrumen variabel citra merek menunjukkan bahwa keseluruhan item pernyataan dinyatakan valid. Diketahui bahwa terdapat satu item pernyataan dengan nilai tertinggi yaitu Mobil Honda Jazz memiliki body mobil yang mudah untuk diingat dengan nilai 0.811. Nilai terendah terdapat pada 
item pernyataan Mobil Honda Jazz dengan nilai 0.586.

memiliki mesin yang berkualitas baik

Tabel-3 Hasil Pengujian Validitas Kualitas Produk

\begin{tabular}{|c|c|c|c|c|}
\hline \multirow{2}{*}{\multicolumn{5}{|c|}{$\begin{array}{l}\text { No. Pertanyaan } \\
\text { Kinerja (Performance) }\end{array}$}} \\
\hline & & & & \\
\hline 16 & $\begin{array}{l}\text { Mesin mobil Honda Jazz irit } \\
\text { bahan bakar }\end{array}$ & 0,1654 & 0,733 & \multirow{2}{*}{$\begin{array}{l}\mathrm{r} \text { hitung }>\mathrm{r} \text { tabel maka } \\
\text { pernyataan valid } \\
\mathrm{r} \text { hitung }>\mathrm{r} \text { tabel maka } \\
\text { pernyataan valid }\end{array}$} \\
\hline 17 & $\begin{array}{l}\text { Mesin mobil Honda Jazz tidak } \\
\text { mudah panas }\end{array}$ & 0,1654 & 0,662 & \\
\hline \multicolumn{5}{|c|}{ Ciri-Ciri Atau Keistimewaan Tambahan (Features) } \\
\hline 18 & $\begin{array}{l}\text { Tampilan warna mobil Honda } \\
\text { Jazz sangat bagus }\end{array}$ & 0.1654 & 0,756 & \multirow{2}{*}{$\begin{array}{l}\mathrm{r} \text { hitung }>\mathrm{r} \text { tabel maka } \\
\text { pernyataan valid } \\
\mathrm{r} \text { hitung }>\mathrm{r} \text { tabel maka } \\
\text { pernyataan valid }\end{array}$} \\
\hline 19 & $\begin{array}{l}\text { Interior mobil Honda Jazz sangat } \\
\text { baik }\end{array}$ & 0.1654 & 0,787 & \\
\hline \multicolumn{5}{|c|}{ Kesesuaian Dengan Spesifikasi } \\
\hline 20 & $\begin{array}{l}\text { Tipe mobil Honda Jazz cocok } \\
\text { bagi pria maupun wanita }\end{array}$ & 0.1654 & 0,786 & \multirow{2}{*}{$\begin{array}{l}\mathrm{r} \text { hitung }>\mathrm{r} \text { tabel maka } \\
\text { pernyataan valid } \\
\mathrm{r} \text { hitung }>\mathrm{r} \text { tabel maka } \\
\text { pernyataan valid }\end{array}$} \\
\hline 21 & $\begin{array}{l}\text { Desain mobil Honda Jazz sangat } \\
\text { menarik }\end{array}$ & 0.1654 & 0,740 & \\
\hline \multicolumn{5}{|c|}{ Keandalan (Reliability) } \\
\hline 22 & $\begin{array}{l}\text { Bentuk mobil Honda Jazz sangat } \\
\text { elegan }\end{array}$ & 0.1654 & 0,555 & \multirow{2}{*}{$\begin{array}{l}\mathrm{r} \text { hitung }>\mathrm{r} \text { tabel maka } \\
\text { pernyataan valid } \\
\mathrm{r} \text { hitung }>\mathrm{r} \text { tabel maka } \\
\text { pernyataan valid }\end{array}$} \\
\hline 23 & $\begin{array}{l}\text { Kecepatan mobil Honda Jazz } \\
\text { memenuhi kriteria }\end{array}$ & 0.1654 & 0,738 & \\
\hline \multicolumn{5}{|c|}{ Daya Tahan (Durability) } \\
\hline 24 & $\begin{array}{l}\text { Fungsi dari mobil Honda Jazz } \\
\text { bukan saja hanya untuk } \\
\text { berkendara }\end{array}$ & 0.1654 & 0,758 & $\begin{array}{l}\mathrm{r} \text { hitung }>\mathrm{r} \text { tabel maka } \\
\text { pernyataan valid }\end{array}$ \\
\hline 25 & $\begin{array}{l}\text { Umur ekonomis mobil Honda } \\
\text { Jazz sangat panjang }\end{array}$ & 0.1654 & 0,818 & $\begin{array}{l}\mathrm{r} \text { hitung }>\mathrm{r} \text { tabel maka } \\
\text { pernyataan valid }\end{array}$ \\
\hline 26 & $\begin{array}{l}\text { Garansi mobil Honda Jazz sangat } \\
\text { baik }\end{array}$ & 0.1654 & 0,846 & $\begin{array}{l}\mathrm{r} \text { hitung }>\mathrm{r} \text { tabel maka } \\
\text { pernyataan valid }\end{array}$ \\
\hline \multicolumn{5}{|c|}{ Estetika } \\
\hline 27 & $\begin{array}{l}\text { Layanan purna jual mobil Honda } \\
\text { Jazz ada dimana-mana }\end{array}$ & 0.1654 & 0,760 & $\begin{array}{l}\mathrm{r} \text { hitung }>\mathrm{r} \text { tabel maka } \\
\text { pernyataan valid }\end{array}$ \\
\hline \multicolumn{5}{|c|}{ Kualitas Yang Dipersiapkan } \\
\hline 28 & $\begin{array}{l}\text { Mobil Honda Jazz memiliki } \\
\text { banyak varian warna }\end{array}$ & 0.1654 & 0,819 & $\begin{array}{l}\mathrm{r} \text { hitung }>\mathrm{r} \text { tabel maka } \\
\text { pernyataan valid }\end{array}$ \\
\hline 29 & $\begin{array}{l}\text { Reputasi perusahaan yang baik } \\
\text { mempengaruhi pembelian mobil } \\
\text { Honda Jazz }\end{array}$ & 0.1654 & 0,842 & $\begin{array}{l}\mathrm{r} \text { hitung }>\mathrm{r} \text { tabel maka } \\
\text { pernyataan valid }\end{array}$ \\
\hline \multicolumn{5}{|c|}{ Kemudahan Perbaikan } \\
\hline 30 & $\begin{array}{l}\text { Layanan service mobil Honda } \\
\text { Jazz mudah diperoleh }\end{array}$ & 0.1654 & 0,732 & $\begin{array}{l}\mathrm{r} \text { hitung }>\mathrm{r} \text { tabel maka } \\
\text { pernyataan valid }\end{array}$ \\
\hline
\end{tabular}

Sumber : Hasil Pengolahan Data 2019

Instrumen variabel kualitas produk menunjukkan bahwa

keseluruhan item peryataan dinyatakan valid. Diketahui bahwa terdapat satu 
item pernyataan dengan nilai tertinggi yaitu Garansi mobil Honda Jazz sangat baik dengan nilai 0.846 . Nilai terendah terdapat pada item pernyataan Bentuk mobil Honda Jazz sangat elegan dengan nilai 0.555 .

\section{Tabel-4 Hasil Pengujian Validitas Keputusan Pembelian}

\begin{tabular}{ccccc}
\hline No. & \multicolumn{1}{c}{ Pertanyaan } & r tabel & r hitung & \multicolumn{1}{c}{ Keterangan } \\
\hline Pengenalan Masalah & & & \\
\hline 31 & $\begin{array}{l}\text { Saya mempunyai keinginan untuk } \\
\text { memiliki mobil Honda Jazz untuk } \\
\text { kebutuhan sehari-hari dalam }\end{array}$ & 0,1654 & 0,660 & $\begin{array}{l}\text { r hitung > r tabel maka } \\
\text { pernyataan valid }\end{array}$
\end{tabular}
beraktivitas

32 Saya tertarik membeli mobil 0,1654 0,674 $\mathrm{r}$ hitung $>\mathrm{r}$ tabel maka Honda Jazz untuk aset pribadi

33 Saya tertarik untuk membeli mobil Honda Jazz karena bujukan teman-teman

\begin{tabular}{|c|c|c|c|c|}
\hline \multicolumn{5}{|c|}{ Pencarian Informasi } \\
\hline 34 & $\begin{array}{l}\text { Tampilan warna mobil Honda } \\
\text { Jazz sangat bagus }\end{array}$ & 0.1654 & 0,756 & \multirow{3}{*}{$\begin{array}{l}\mathrm{r} \text { hitung }>\mathrm{r} \text { tabel maka } \\
\text { pernyataan valid } \\
\mathrm{r} \text { hitung }>\mathrm{r} \text { tabel maka } \\
\text { pernyataan valid } \\
\mathrm{r} \text { hitung }>\mathrm{r} \text { tabel maka } \\
\text { pernyataan valid }\end{array}$} \\
\hline 35 & $\begin{array}{l}\text { Saya berencana menggunakan } \\
\text { mobil Honda Jazz untuk keluarga }\end{array}$ & 0.1654 & 0,657 & \\
\hline 36 & $\begin{array}{l}\text { Saya berencana membeli mobil } \\
\text { Honda Jazz karena arahan dari } \\
\text { teman }\end{array}$ & 0.1654 & 0,746 & \\
\hline \multicolumn{5}{|c|}{ Evaluasi Alternatif } \\
\hline 37 & $\begin{array}{lcc}\text { Saya akan } & \text { merekomendasikan } \\
\text { mobil } & \text { Honda } & \text { Jazz kepada orang } \\
\text { lain } & & \end{array}$ & 0.1654 & 0,552 & $\begin{array}{l}\mathrm{r} \text { hitung }>\mathrm{r} \text { tabel maka } \\
\text { pernyataan valid }\end{array}$ \\
\hline 38 & $\begin{array}{l}\text { Saya akan mempertimbangkan } \\
\text { untuk menggunakan mobil Honda }\end{array}$ & 0.1654 & 0,654 & $\begin{array}{l}r \text { hitung }>r \text { tabel maka } \\
\text { pernyataan valid }\end{array}$ \\
\hline & 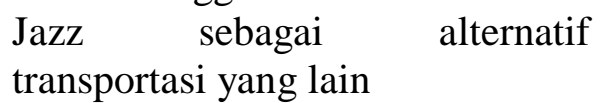 & & & \\
\hline 39 & $\begin{array}{llr}\text { Karena bermanfaat dan } \\
\text { kebutuhan, }\end{array}$ & 0.1654 & 0,710 & $\begin{array}{l}r \text { hitung }>r \text { tabel maka } \\
\text { pernyataan valid }\end{array}$ \\
\hline & $\begin{array}{l}\text { mobil Honda Jazz untuk } \\
\text { bepergian }\end{array}$ & & & \\
\hline 40 & $\begin{array}{l}\text { Saya mempunyai selera terhadap } \\
\text { merek mobil Honda Jazz }\end{array}$ & 0.1654 & 0,631 & $\begin{array}{l}\mathrm{r} \text { hitung }>\mathrm{r} \text { tabel maka } \\
\text { pernyataan valid }\end{array}$ \\
\hline \multicolumn{5}{|c|}{ Tahap Pembelian } \\
\hline 41 & $\begin{array}{l}\text { Saya membeli mobil Honda Jazz } \\
\text { karena menyukai desainnya }\end{array}$ & 0.1654 & 0,750 & \multirow{3}{*}{$\begin{array}{l}\mathrm{r} \text { hitung }>\mathrm{r} \text { tabel maka } \\
\text { pernyataan valid } \\
\mathrm{r} \text { hitung }>\mathrm{r} \text { tabel maka } \\
\text { pernyataan valid }\end{array}$} \\
\hline 42 & $\begin{array}{l}\text { Saya membeli mobil Honda Jazz } \\
\text { karena situasi ekonomi }\end{array}$ & 0.1654 & 0,802 & \\
\hline 43 & $\begin{array}{l}\text { Saya puas menggunakan mobil } \\
\text { Honda Jazz }\end{array}$ & 0.1654 & 0,617 & \\
\hline \multicolumn{5}{|c|}{ Perilaku Pasca Pembelian } \\
\hline 44 & $\begin{array}{l}\text { Saya akan melakukan pembelian } \\
\text { ulang mobil Honda Jazz }\end{array}$ & 0.1654 & 0,770 & \multirow{2}{*}{$\begin{array}{l}\mathrm{r} \text { hitung }>\mathrm{r} \text { tabel maka } \\
\text { pernyataan valid } \\
\mathrm{r} \text { hitung }>\mathrm{r} \text { tabel maka }\end{array}$} \\
\hline 45 & Saya mendapatkan & 0.1654 & 0,686 & \\
\hline
\end{tabular}


mobil Honda Jazz dari berbagai

pernyataan valid sumber

Sumber : Haasil Pengolahan Data 2019

Instrumen variabel keputusan pembelian menunjukkan bahwa keseluruhan item pernyataan dinyatakan valid. Diketahui bahwa terdapat satu item pernyataan dengan nilai tertinggi yaitu Saya membeli mobil Honda Jazz karena situasi ekonomi dengan nilai 0.802. Nilai terendah terdapat pada item pernyataan
Saya akan merekomendasikan mobil Honda Jazz kepada orang lain dengan nilai 0.552 .

Dengan kesimpulan variabel yang reliabel memiliki nilai diatas 0,600 dan merupakan construct yang kuat. Dan untuk menguji reliabilitas ini menggunakan SPSS.

Tabel-5 Hasil Pengujian Reliabilitas

\begin{tabular}{lllll}
\hline No. & Variabel & r hitung & r tabel & Keterangan \\
\hline 1 & Citra Merek & 0,765 & 0,600 & Reliabel \\
2 & Kualitas Produk & 0,769 & 0,600 & Reliabel \\
3 & Keputusan Pembelian & 0,763 & 0,600 & Reliabel \\
\hline
\end{tabular}

Sumber : Hasil Pengolahan Data 2019

Berdasarkan tabel diatas menunjukkan bahwa ketiga variabel yang diteliti dalam penelitian ini dinilai reliabel yang berarti bahwa alat ukur dalam penelitian ini merupakan alat ukur yang konsisten dan dapat dipercaya.

Tabel-6: Uji Parsial

\begin{tabular}{lcccccc}
\hline \multirow{2}{*}{ Variabel } & \multicolumn{7}{c}{ Parameter } \\
\cline { 2 - 7 } & Mult. R & R Square & Konstanta & Koef. B & Sig. & t hitung \\
\hline Citra Merek & \multirow{2}{*}{0.773} & 0.603 & \multirow{2}{*}{3.898} & 0.275 & \multirow{2}{*}{0.010} & 4.623 \\
Kualitas Produk & & & & 0.366 & & 5.713 \\
\hline Pengujian Signifikansi & & & & \\
\hline
\end{tabular}

Koefisien determinasi $\left(\mathrm{R}^{2}\right)$ sebesar 0,603 berarti $60,3 \%$ variabel keputusan pembelian bisa diterangkan oleh variabel citra merek dan kualitas produk, atau dapat diartikan bahwa citra merek dan kualitas produk memiliki kontribusi terhadap keputusan pembelian sebesar $60,3 \%$ sedangkan sisanya $39,7 \%$ merupakan kontribusi variabel lain yang tidak diteliti.

\section{Hipotesis Parsial Citra Merek terhadap Keputusan Pembelian}

Untuk pengaruh citra merek secara parsial terhadap keputusan pembelian dengan tingkat signifikan $(\alpha)=10 \%$, degree of freedom $(\mathrm{df})=$ $(\mathrm{n}-2)=100-2=98$ diperoleh $\mathrm{t}_{\text {tabel }}=$ 1,661. Berdasarkan Tabel 6, menunjukan bahwa $t_{\text {hitung }}=4,623>t_{\text {tabel }} 1,661$ dan nilai sig. $0.000<\alpha 0.10$, maka $\mathrm{H}_{0}$ ditolak. 
Dengan demikian dapat disimpulkan bahwa citra merek secara parsial berpengaruh terhadap keputusan pembelian.

\section{Hipotesis Pengaruh Parsial Kualitas Produk terhadap Keputusan Pembelian}

Untuk pengaruh kualitas produk secara parsial terhadap keputusan pembelian dengan tingkat signifikan $(\alpha)=10 \%$, degree of freedom $(\mathrm{df})=$ $(\mathrm{n}-2)=100-2=98$ diperoleh $\mathrm{t}_{\text {tabel }}=$ 1,661. Berdasarkan Tabel 6, menunjukan bahwa $t_{\text {hitung }}=5,713>\mathrm{t}_{\text {tabel }}$ 1,661 dan dan nilai sig. $0.000<\alpha \quad 0.10$ ) maka $\mathrm{H}_{0}$ ditolak. Dengan demikian dapat disimpulkan bahwa kualitas produk secara parsial berpengaruh terhadap keputusan pembelian.

Pengujian hipotesis secara simultan dilakukan dengan uji statistik $\mathrm{F}$, didapatkan nilai signifikan model regresi secara simultan sebesar 0.000 , nilai ini lebih kecil dari significance level 0.1 (10\%), yaitu $0,000<0,1$. Selain itu dapat dilihat juga dari hasil perbandingan antara dan $\mathrm{F}_{\text {tabel }}$ yang menunjukkan nilai $F_{\text {hitung }}$ sebesar 71,986 sedangkan $F_{\text {tabel }}$ sebesar 2,76. Dari hasil tersebut terlihat bahwa $F_{\text {hitung }}$ $>\mathrm{F}_{\text {tabel }}$ yaitu 71,986 > 2,76. Sehingga keputusan tolak $\mathrm{H}_{0}$. Artinya, bahwa secara simultan variabel independen yaitu citra merek dan kualitas produk berpengaruh secara signifikan terhadap variabel dependen yaitu keputusan pembelian.

\section{Pembahasan}

Semua indikator pada variabel citra merek berada pada kriteria setuju yaitu logo produk, nama produk, harga produk, kemudahan menggunakan produk, efektifitas, sesuai harapan, berkualitas baik, sesuai dengan status sosial, gaya hidup, lingkungan, penilaian terhadap kualitas, mudah diingat, keunikan, mencerminkan masyarakat atas, mencerminkan masyarakat dewasa.

Semua indikator pada variabel kualitas produk berada pada kriteria setuju yaitu indikator kekuatan produk, ketahanan produk, tampilan produk, interior produk, variasi produk, desain produk, bentuk produk, kecepatan produk, fungsi produk, umur ekonomis produk, garansi produk, layanan purna jual, warna produk, reputasi perusahaan dan layanan service produk.

Satu indikator variabel keputusan pembelian berada pada kriteria sangat setuju yaitu indikator referensi dan indikator lainnya berada pada kriteria setuju yaitu kebutuhan, rangsangan internal, rangsangan eksternal, sumber pribadi, keluarga, saran teman, pengalaman, pertimbangan, manfaat, merek, pembelian karena suka, pembelian karena situasi, kepuasan dan pembelian ulang.

\section{KESIMPULAN DAN SARAN}

\section{Kesimpulan}

Setiap indikator yang terdapat pada variabel citra merek dan kualitas produk semuanya dapat meningkatkan keputusan pembelian. Peningkatan pembelian dapat terus terjadi jika variabel citra merek dan kualitas produk secara bersama - sama diperhatikan hingga terus ditingkatkan menjadi lebih baik lagi dan terus adanya evaluasi jika ada salah satu atau beberapa indikator dari variabel citra merek maupun kualitas produk mengalami kelemahan dibanding produk pesaing. Tetapi semua indikator telah diterima atau disetujui oleh konsumen terbukti dari hasil penelitian bahwa semua indikator dari setiap variabel disetujui oleh responden.

Korelasi (hubungan) antara citra merek dan kualitas produk mempunyai 
hubungan yang kuat dan searah karena nilainya positif. Pengaruh parsial citra merek terhadap keputusan pembelian menunjukan pengaruh positif antara citra merek terhadap keputusan pembelian. Pengaruh parsial kualitas produk terhadap keputusan pembelian menunjukan pengaruh positif antara kualitas produk terhadap keputusan pembelian. Diketahui pula bahwa variabel kualitas produk lebih besar dan dominan memberikan pengaruh terhadap keputusan pembelian dibandingkan variabel citra merek.

Pengaruh simultan citra merek dan kualitas produk terhadap keputusan pembelian menunjukan bahwa citra merek dan kualitas produk berkontribusi terhadap keputusan pembelian dan terdapat kontribusi variabel lain yang tidak diteliti dalam penelitian ini.

\section{Saran}

Kepada Perusahaan: Untuk meningkatkan daya beli, maka perusahaan harus memperhatikan masalah citra merek karena memberikan citra yang baik mengenai produk didalam benak konsumen sangat diperlukan agar konsumen selalu mengingat bahwa produk yang dipilih atau dibelinya merupakan produk terbaik. Untuk meningkatkan daya beli, maka perusahaan juga harus memperhatikan kualitas produk, karena kualitas produk yang baik dan paling unggul adalah produk yang dicari oleh konsumen sehingga perusahaan mampu bersaing diantara produk pesaing.

Daya saing pada produk mobil Honda Jazz dinyatakan terbilang cukup tinggi, penulis menyarankan produk mobil Honda Jazz harus tetap mempunyai ciri khas supaya mampu bersaing dengan perusahaan perusahaan sejenis lainnya. Pada perusahaan agar mendukung karyawannya sehingga terus dapat meningkatkan pelayanan lebih baik lagi dalam menawarkan produk sampai menangani konsumen saat melakukan perbaikan dan pemeliharaan (service). Bagi karyawan, dituntut lebih meningkatkan kreativitas dan inovasi dalam dirinya guna mengoptimalkan kinerja. Karena walaupun sudah didukung oleh lingkungan kerja yang baik, jika motivasi masing - masing karyawan kurang dan tidak adanya kreativitas dan inovasi maka hal tersebut tetap akan mempengaruhi hasil produknya.

Kepada Peneliti Selanjutnya: Hasil penelitian ini diharapkan mampu membantu peneliti selanjutnya untuk dijadikan acuan pada penelitiannya. Diharapkan peneliti selanjutnya dapat melakukan penelitian lanjutan untuk mencari tahu pengaruh citra merek dan kualitas produk terhadap variabel dependen lainnya. hasil ini mendasari peneliti untuk memberikan rekomendasi terhadap peneliti selanjutnya untuk meneliti citra merek dan kualitas produk dengan tambahan dimensi lain dari penelitian ini.

\section{DAFTAR PUSTAKA}

Amalia, Suri. 2017. "Pengaruh Citra Merek, Harga, dan Kualitas Produk Terhadap Keputusan Pembelian Handphone Merek Xiaomi di Kota Langsa."

Andrew, Sikula. 2011. Manajemen Perencanaan, jakarta

Anoraga, Pandji. 2009. Manajemen Pemasaran. Jakarta : PT. Rineka Cipta

Arif, Anissa R dan Made Adhi G. 2018. "Pengaruh Brand Image dan Kualitas Produk Terhadap Keputusan Berkunjung ke Resto Foresthree."

Assuri, Sofjan. 2013. Manajemen Pemasaran. Jakarta : PT. Raja Grafindo 
Buchari, Alma. 2013. Manajemen Pemasaran dan Pemasaran Jasa. Bandung : Alfabeta

Chriyanti, Irra. 2011. Manajemen. Jakarta

: Gramedia

Desy, Irana dan Rahmat Hidayat. 2017. "Pengaruh Citra Merek dan Harga Terhadap Keputusan Pembelian pada Sekolah Tinggi Ilmu Manajemen Sukma Medan."

Elvi Yati, Dodi Devianto, Y. A. (2013). TRANSFORMASI $B O X-C O X$ PADA ANALISIS REGRESI.2(2),115-122.

Fiani, Margaretha dan Edwin Japarian. 2012. "Analisis Pengaruh Food Quality dan Brand Image Terhadap Keputusan Pembelian Roti Kecik Toko Roti Ganep's di Kota Solo."

Handoko, Hani 2010. Manajemen Pemasaraan : Kualitas Produk. Edisi Kedua. Yogyakarta

Hasibuan, Malayu. 2011. Manajemen : Dasar, Pengertian dan Masalah (Edisi Revisi)

Kotler, Philip dan Keller. 2008. Manajemen Pemasaran Edisi ke-11 jilid 2. Jakarta : Erlangga

Kotler, Philip dan Keller. 2008. Manajemen Pemasaran Edisi ke-13 jilid 2. Jakarta : Erlangga

Kotler, Philip dan keller. 2009. Manajemen Pemasaran edisi ke-13 Jilid 2. Jakarta: Erlangga.

Kotler, Philip dan Gary Amstrong. 2012. Prinsip-Prinsip Pemasaran Edisi 13 jilid 1. Jakarta

Laksana, Fajar. 2008. Pengetian Citra Merek, Bandung

Peter, Paul dan Jerry C Olson. 2013. Strategi Pemasaran Jilid 1 dan Jilid 2. Jakarta : Salemba

Reminta Lumban Batu. (2013). Analisis Citra Perguruan Tinggi Amerika Serikat Terhadap Keputusan Untuk Melanjutkan Studi (Survei Pada Komunitas Persatuan Mahasiswa Indonesia Di Amerika Serikat)
Universitas Pendidikan Indonesia. 48-72.

Robins, P. Steven dan Coutler, Mary. 2010. Fungsi-fungsi Manajemen

Sugiyono. 2015. Metode Penelitian Kuantitatif, Kualitatif, dan R\&D. Alfabeta, Bandung.

Sulistyawati, Praba. 2010. “Analisis citra merek dan kualitas produk terhadap keputusan pembelian laptop merek acer di kota Semarang."

Sumarwan, Ujang. 2011. Brand Image. Jakarta.

Tjiptono, Fandy.2008. Strategi Bisnis Pemaasaran. Andi. Yogyakarta

Tjiptono, Fandy 2009, Strategi Pemasaran, Edisi Kedua, Cetakan Ketujuh, Yogyakarta : Andi Offset

Utari, Dwi Dian. 2016. "Pengaruh Brand Image dan Kualitas Produk Terhadap Keputusan Pembelian Indihome Pada PT. Telkom Langsa." 